\title{
CREATIVE OR ANALITICAL WAY FOR CAREER DEVELOPMENT? RELATIONSHIP MARKETING IN THE FIELD OF INTERNATIONAL BUSINESS EDUCATION
}

\author{
Marina MARKOVA ${ }^{1}$, Artur MODLIŃSKI ${ }^{2 *}$, Luís MOREIRA PINTO \\ ${ }^{1}$ Moscow State University, Business School \\ 1-52 Leninskie Gory, 119234, Moscow, Russia \\ ${ }^{2}$ University of Łódź, Faculty of Management, Department of Management \\ 22/26 Matejki Street, 90-237 Lodz, Poland \\ ${ }^{3}$ University of Beira Interior, Faculty of Architecture, Department of Civil Engineering and Architecture, \\ Calçada Fonte do Lameiro, 6201-001 Covilhã, Portugal \\ ${ }^{3}$ CITAD Research Center, Rua da Junqueira, 188-198, 1349-001, Lisbon, Portugal
}

Received 18 November 2018; accepted 11 November 2019

\begin{abstract}
The article presents a strategic model of the partnership in the field of business education that takes into account the specificity of the globalization and current trends on the job markets. The main research tasks were to consider the theoretical bases of relationship marketing and to examine the major trends and challenges of the job market in Russia. The article includes the results of the research on the goals in life and motivation of secondary school students, the survey among the university professors on their opinions about why students decide to study, and also the results of the international research among students of European and Russian universities. The article present various activities that the business school can use to boost the cooperation between its main shareholders. The authors suggest a matrix of interaction between universities and partner companies which composes of the tangible/intangible resources and tangible/intangible effects with the characteristics of their impact and effectiveness for both the companies and universities.
\end{abstract}

Keywords: business education, interaction, job market, relationship marketing.

\section{Introduction}

The relationship marketing became one of the key factors of the business schools and universities' success in the field of business education. The universities around the world develop and actualize successively their programs to strengthen their market position whereas the companies obtain the professionals for their businesses' purposes. Such symbiosis is especially visible in the digital era where information plays an essential role in the competitive games. At the same time, the development of partnership between such entities faces several limitations. The bumpy environment, economic crises, automation and changes in students'

*Corresponding author. E-mail: artur.modlinski@uni.lodz.pl 
goals lower the validity of skills and knowledge received, reducing the motivation to study. In consequence, the symbiosis between university and business starts to weaken. The strategies to reinvent the successful partnerships between these entities differ around the world. The authors decided to analyze the Russian business education's environment to detect potential strategies that would improve the partnership between universities and companies. To realize these goals, the key trends in the Russian job market have been identified, the field research among secondary school students in Moscow, Russia and Moscow's region have been realized, the motivations of secondary schools' students for choosing a profession have been identified. Consequently, the most effective ways of interaction between business structures and universities are proposed.

\section{Literature review}

The development of relationship-oriented market strategy is intrinsically connected to the post war experiences of American and British practitioners. Over the years, public relations and relationship-oriented marketing became the integral part of organizations functioning in both private and public sector. Relationship marketing makes clients more satisfied and loyal as well as it increases the performance of the whole organization (Saelee, Jhundrain, \& Muenthaisong, 2015). Its main goal is to create strong connections between the clients and the company (Rouse \& Aberle, 2019), and to turn the first time clients into the advocates and partners who promote the organization (Ackerman \& Schibrowsky, 2007). Such authors as Roger Bennett (2006) and R. G. Barlow (2000) prove that the relationship marketing is used not only by multinational corporations and governmental agencies but also by nongovernmental organizations, cultural institutions, high schools and universities who noticed that the customer satisfaction is essential for successful development and survival on the market (DeShields, Kara, \& Kaynak, 2005). Luminița Nicolescu (2009) denotes, however, that universities in general are not using all marketing tools and concepts which are typical for business sector but they rather try to adjust the existing concepts into their specific needs. The relation-oriented strategy is a point of interest for business schools due to the constant need to attire attention of prospective students, provide them the best quality programs of studies with an emphasis on the business practice and attractive employment after graduation. The students' successes allow the business schools moving up in the rankings, gaining prestige and build market position. However, some authors claim that the financial profit of the business schools became their primary interest and relationship marketing is a tool that can lead to several misunderstandings between shareholders. Kristine Zaksa (2012) suggests, reversely, that the emotional satisfaction, spiritual values and loyalty to the organization should be perceived as the core values in business education. Oscar W. DeShields Jr., Ali Kara and Erdener Kaynak (2005), claim that students, higher education institutions and society form a what create several societal benefits that cannot be fully commercialized. Some other authors, such as Cristinel Constantin (2011) and Larry H. Litten (1980) inform, however, that due to the decrease of the number of the young people, economic instability and global competitiveness between universities, the financial benefits of relationship strategies should not be ignored. Tomasz Domański (2014) as well as Duncan Moore and Jana Lay-Hwa. 
Bowden-Everson (2012) also show that since the globalization process increased the competitiveness between universities around the world the relationship marketing became the direct tool in the competitive games. Nevertheless, the students are perceived as the most valuable resources of the university and an important asset for future development (Grönroos, 1989). Although the British and American business schools are still ranked as the best in the world ((Binsardi \& Ekwulugo, 2003), the new marketing approach used by Japanese, Spanish and French schools helped them to advance significantly. It proves that market-oriented strategy and effective marketing plan is essential for the constant and stable development of the educational institution (Białoń, 2015).

From the commercial perspective, the objective of the relationship marketing is to attract, maintain and build relationships between partners (Ackerman \& Schibrowsky, 2007). The similar approach used to be applied in the education sector. Iliuță Costel Negricea, Emanuela Maria Avram, and Raluca Cristina Eftimie (2011) suggest that one of the most important challenges of business schools is to build a long-term relationship with their main shareholders as well as to attract, retain and regain the students. However, the process of building such type of relationships in the field of business education is not fully examined. Tahir Rashid and Razak Raj (2006) claim that we need to provide good service quality, experience, shared values, proper communication and trust to build loyalty and commitments between partners which are the main goals of the relationship marketing from the business school perspective (Carvalho \& Oliveira Mota, 2010). Notwithstanding, such concepts as good service quality or experiences are not perceived by all students in the same way. For this reason, the schema of Rashid and Raj can lead to some misunderstandings. Negricea, Avram and Eftimie (2011) hold the opinion that some students can be even less satisfied with higher quality of services and feel disgruntled with difficult programs. Zaksa (2012) suggests that students' perceived quality is rather associated with academic staff skills and attitudes, curricula and course content, learning outcomes and readiness for the labour market. Michael Fontaine (2014) claims that such relationship marketing techniques as individualized attention and communication are decisive factors in achieving success in business education field. Paul D. Umbach and Stephen R. Porter (2002) confirm such statements showing that small institutions where individual approach is used have more satisfied students. Kimberley K. Powell and Melanie Powell Rey (2015) stress that the current students' expectations and opinions should be of superior value but other groups cannot be ignored. Anna Drapińska (2016) places an emphasis on the particular importance of the students' loyalty which can be built by collaboration, mutual involvement and trust.

More and more frequently, the business schools are developing the research programs to understand the expectations of their clients (students) and other shareholders (Zaksa, 2012). John Nicholls, John Harris, Eleanor Morgan, Ken Clarke, and David Sims (1995) found that an understanding of the key shareholders (students, alumni) is a crux in relationship's building process. It helps to develop the successful strategies and gain the competitive advantage. Drapińska (2016) suggests that there are three phases of the contacts between the school and the student: pre-sale, sale and post-sale. At the pre-sale stage a school tries to convince the student that it is a good place to learn. At the sale stage the students are learning and exchanging experiences with the staff and other stakeholders. They are seeking for 
both emotional and affective bonds with their university and such chance for psychological closeness cannot be ignored by the school (Bowden \& Wood, 2011). At the post-sale stage students start their professional career on the basis of the knowledge and skills gained at the sale stage. The current cases show that many business schools take care only for the first two stages. They ignore the current research proving that building reciprocal relationships between partners in education is an ongoing process and it should be outreached into the maximum to be the most effective for all partners (Helgesen, 2008). The university should help the students in finding the attractive traineeship and employment as far as alumni can become in the future the brand ambassadors of the university. They can transfer their feelings to the potential clients, recommend the prospective students, or hold the courses as practitioners and develop the business network of the whole institution. According to Ogunnaike Olaleke Oluseye, Borishade Taiye Tairat, and Jeje Olumide Emmanuel (2014) such a form of relationship is called "the parent relationship" and it increases the frequency of positive recommendation and word-of-mouth.

Robert Seliga and Michał Chmielecki (2012) claim that the key factors that determine the choice of a university include a position in the rankings of the universities, good teaching staff and a reputation among current or ex-students. The focus on professional teaching staff is especially interesting from the point of view of the relationship marketing. It is observed that students request the lectures rather with practitioners than with theoreticians. Building stable relationship networks between business school and companies can be perceived as a good tool which helps to meet these needs of the students. In other words, the relationship marketing techniques and strategies can be the key factors which shape the image of the business school and encourage the prospective students to enroll in its courses.

To develop the relationship networks the business schools are obliged to identify their key shareholders. David G. Tonks and Marc Farr (1995) claim that these are mainly students. Constantin (2011) suggests that these are also alumni, employers and authorities. James H. McAlexander, Harold F. Koenig, and John W. Schouten (2006) denote that the business schools should integrate these groups by investing in university's brand communities. Such entities can increase the chances for the attractive employment's opportunities of the actual students and their total satisfaction. Such communities should place special emphasis on the reciprocity what help to understand the expectations of the students and to support symmetric communicational model (Guolla, 1999). According to Basheer A. M. Al-Alak (2006) the loyalty, positive word of mouth, students' satisfaction and promotion lead to the enhancement of the university image and, consequently, larger number of students. This is the main reason why business schools try to find the most effective relationship marketing tools. Robert Ackerman and John Schibrowsky (2007) suggest the bonding activities which can result in higher retention rate and loyalty. These are financial bonding, social bonding and structural bonding. The financial bonding is only a base in the relationship building. The examples are: scholarships, work-study opportunities, inexpensive daycare, subsidized transportation, academics, tuition waivers and discounts, affordable health care (Ackerman \& Schibrowsky, 2007). More important is social bonding which comprises customized and personalized communication, providing necessary information, extracurricular activities, cultural events, social activities, awards and celebration events, conversation spaces, meeting 
with authorities, research opportunities, opinion surveys, mentoring and tutoring (Ackerman \& Schibrowsky, 2007). These authors perceive the structural bonding as the crucial action in relationship building as it is a base of the student empowerment's process. A student which has the power to make a decision about university's future or its particular program is loyal and engaged. The engagement, in turn, is perceived by Moore and Lay-Hwa. BowdenEverson (2012) as the most effective part of the relationship marketing programs which help to build long-term relationship between shareholders. According to Marcelo Gattermann Perin, Claudio Hoffmann Sampaio, Cláudia Simões, and Rosiane Pólvora de Pólvora (2012) the business school should also place an emphasis on building trust and perceived high value as far as they are positively correlated with commitment and engagement of the students.

David W. Letcher and Joao S. Neves (2010) suggest several important factors which are overlapping with aforementioned social and structural bounding and can be introduced with the aid of relationship marketing strategies. There are the internships, service to the community, leadership experiences, activity in campus organization and proactive career planning. All of them have positive impact on the satisfaction and loyalty of the students and can contribute to closer cooperation between main shareholders such as companies, managers and business consultants. A similar view is presented by Silke Jurkowitsch, Claudio Vignali, and Hans Ruediger Kaufmann (2006) in their "A Student Satisfaction Model for Austrian Higher Education Providers Considering Aspects of Marketing Communications" where student satisfaction is dependent on non-relationship inducing factors (such as the students personality and economic climate) as well as on relationship inducing factors (the teaching service, culture and environment, relationship and university marketing) in which relationship networks and cooperation between key shareholders are extremely important. However, little is known about the relationship strategies of business schools outside the leading centers in Europe and North America. The authors of the article focus on the Russian business education's market and its challenges in the area of the relationship marketing which develop simultaneously after the Soviet Union's collapse.

\section{Materials and methods}

The identification of key trends in the Russian job market and education was conducted by an analytical overview of essential and perspective professions in the modern Russian job market as well as with the method of analysis of the proposed vacancies and resumes distribution dynamics on the job market in Moscow and Moscow region. The field research among students of secondary schools in Moscow and Moscow region and universities' professors was conducted with the method of non-repeated selective absentia survey (a) to establish the relationship between the degree of awareness among students and lecturers of the "weal" concept as a factor that affects the motivation to study, having a relationship with the profession the students have chosen, and personal happiness, (b) to determine the motivation of today's Russian schoolchildren for choosing profession which are based on sustainable patterns of thinking, in a non-survival own position in life, and to (c) identify the relationship between the choice of a profession that a student tends to get with the understanding of personal "dream in life". The identification of the most effective ways of the interaction between 
the business structures and universities was conducted by the secondary data's analysis: the results of the international research among students of European, Russian universities and separately Moscow State University (MSU) (“Trendence Graduate Barometer") as well as with the survey among partner companies of the business school on the subject of their interaction, specific activities and their effectiveness.

\section{Procedures and results}

According to the results of the research carried out by the international research company Universum, the most attractive attributes of the university are: reputation and image (a high place in the ranking, prestige, successful graduates), student life (open environment, creative and dynamic atmosphere, extracurricular activities), employment (knowledge and skills needed for further work, high percentage of employability among graduates, good reputation among employers), the quality of education (excellent teachers and lecturers, practical classes, the quality and variety of programs). At the same time, the most frequently met career types of Russian students are: "hunter", "internationalist" and "careerist"; the other types are: "entrepreneur", "harmoniser", "idealist", "leader". Thus, the researchers came to the conclusion, that modern students are very competition-oriented, internationally-oriented and career development-oriented.

In addition to these results and according to the job market monitoring data, there has been no adequate balance between the demand for specialists and actual professionals who could get the job offered just after the graduation. The significant share of the graduates is forced to either work in area they are not the specialists after the studies or be reoriented. It concerns especially such areas as sales and production. This trend is typical for post-Soviet countries. At the Polish market $1 / 2$ of all graduates is not working in their profession. It seems that a substantial number of candidates still choose the studies taking into account the interests, ignoring the chances for finding employment after the graduation.

In an effort to identify the causes of such situation on the job market, the researchers of MSU Business School examined the opinions of 346 students of Moscow secondary schools schoolchildren from 8th, 9th, 10th and 11th classes. This survey was devoted to studying the characteristics of students' future profession choice and the formation of their professional position and the life orientations. In turn, these findings allow to make the assumptions about how much the students are ready to implement a conscious choice of profession and to seek demanded profession.

Specific classes were chosen by the researchers in order to establish the nature of the dynamic change in students' attitudes and professional preferences starting from:

- the 8 th class when there is no question of defining future profession in front of them and they continue a systematic study at school;

- in the 9th class, when students can already decide to leave school and go to vocational college;

- in the 10th and 11th classes, when questions of professional choice become more urgent, and their decision - necessary. 
In this survey, special attention was paid to the students' desire to be engaged in business and to set up their own business. The questionnaire consisted of the following questions:

(1) "Age (full years)";

(2) "Gender (male/female)";

(3) "In which class do you study?";

(4) "Where do you plan to study after graduation?";

(5) "What profession would you like to obtain?";

(6) "What exactly do you expect from higher education (after graduation)?";

(7) "What is your dream in life?".

All questions were open. However, only the first and third questions suggested further analysis of specific direct answers. The analysis of the responses to other questions suggested the preliminary number of encoding options for answers in order to enable their further statistical processing. It is worth noting that the initial responses to the sixth and seventh questions were given by respondents in absolutely free formula, and the authors faced a wide range of responses options. The authors considered response categories in order to systematize the responses received and to simplify the analysis procedure.

The answer options for the fourth question were the following: "I do not know", "school", "army" and "college". The following response options were received as the answers to the fifth question: "I do not know", "information technology specialist", "public relations specialist", "actor", "doctor", “designer", “journalist", and others. Categories of responses to the sixth and seventh questions included: "no", "nothing", "I do not know", "active life", "interesting job", "financially secure life", "public recognition", "knowledge", "productive life", "freedom”, "happiness of others", "self-development", "situational need", "happy family life", "pleasure", "creativity", "love", "locked position".

The decision of using the same answer categories for the sixth and seventh questions was made by the researchers in order to allow correlating attitudes of students from different classes and their expectations from higher education, as well as to assess the level of the direct relationship between them.

The last question from the questionnaire was regarded as a key to the study results. The analysis of the responses to this question allowed the authors to interpret the answers to the question about the expectations of higher education in the most correct way. For example, the same expectation from higher education as "financially secure life" can be purely pragmatic, self-oriented, imposed by the specific patterns of behavior in modern society, shaping the dream of the "happy family life", or may be creative and innovative, in terms of personal development where such dream can be in line with the "happiness of others".

The research was conducted as non-repeated selective absentia survey. At the first stage of the processed survey data analysis, the correlation analysis of data obtained during the survey was carried out to establish the degree of relationship between the expected future profession, expectations of students from graduation and their attitudes. Cheddok's scale was used to assess the degree of interconnections. The results obtained allow drawing conclusions on the theoretical level of professional orientation of the students.

The results showed a clear lack of understanding by the students of their professional path and the specific expectations from the higher education. The most popular answers 
to the question about their preferred profession were: "I do not know", "economist", "Manager". The first one reflects a negative situation with the professional orientation itself and the others demonstrate stereotypic opinions linked with the social prestige. The most frequent answers to the question about the expectations from getting higher education were: "financially secure life", "productive life", "I do not know". This shows also just general stereotypic points of view and the absence of understanding in the last answer option. The most popular answers to the question about a dream in life were: "public recognition", "financially secure life", "no dream". This confirms the conclusions concerning the previous question and is the most dramatic.

The identified problems need to be analyzed in terms of their impact on the students' objectives for learning at the university. To address this analytical task, the authors conducted a survey among the lecturers of Russian universities with the non-repeated selective method. In this case the lecturers acted as experts, since they can assess the degree of students' "inclusion" in the educational process and their motivation to study. Otherwise, personal assessment of motivation in this case would be purely subjective and it would be under the strong influence of personality and psychological characteristics of the students. In determining the required number of experts to conduct the survey the authors based on a statistical approach. Specifically, according to the statistical calculations of sociology experts, the optimal number of experts should be in the range of 10 to 30 people. However, in order to improve the reliability of the responses, 50 university professors were interviewed, given the fact that they differ by the age, work experience and specialty.

The results from the study made on the Russian universities' professors showed that about $70 \%$ of them believe that the main reason the students decide to study is a diploma. According to the lecturers, under the term "employability" one part of the students understands a "high-paying job" and the other - the rapid professional promotion. $10 \%$ of the lecturers believe that students demand just financially secure life and $20 \%$ - public recognition. Only $22 \%$ of the lecturers noted gaining knowledge as the objective of the students' education. The results of the survey among lecturers suggest that students' motivation to study and create their own business is at a low level. Consequently, the job market gets the alumni from the universities who do not realize the spheres which would be of their direct interest and in which they could manifest their potential and creativity in the most successful way.

\section{Suggestions and discussions}

The authors see the solution to the problems described above in the formation of the university system of relationships with the shareholders functioning on the basis of marketing principles. This approach at the highest extent will allow to take into account the interests of each party and increase the efficiency of interaction which was proven by Leonard Berry (2002) in his initial research about relationship management. In particular, the interaction with corporate and academic world could be the basis for sustainable development of a business school helping students to get practical experience, to form their professional orientation and enhance their interest and motivation for study. 
The structure of relationship marketing in the aspect of the problems identified is combined into two main strategic units: (1) relationships between the university and secondary schools in the direction of developing joint programs of vocational guidance, forming motivation of the future students to study and (2) relationships between the university and business structures for conducting career guidance and career events, forming motivation of the current students to study and a desire to develop themselves professionally in a particular area. According to the observation of the current business schools' strategies within these two blocks, the authors proposed the synthesis of the activities which contribute to the quality's improvement of vocational guidance for secondary school students, motivation of university students and the skills of the graduates. These areas do not require significant financial or time costs as they fit into the framework of already implemented educational and extracurricular activities of the high school.

A. The actions linked with the "relationships between the university and secondary schools".

As the practice shows, they include mainly the "schools for young" (entrepreneurs, managers, etc.), career guidance workshops and festivals of science. This bloc of activities is corresponding to the targeting which is the key element of modern companies (Lynn, 2011). After the segmentation process companies are selecting the customers whom they want to offer particular products or services. In the perspective of universities both segmentation and targeting are made automatically. Establishing relationship on the education market is basing on the "upbringing of potential students". During this phase the universities try to present their offer, dispel doubts and build loyalty. The students who take part in such activities feel more relaxed, they know what to expect from the university, having an opportunity to meet with the staff.

B. The actions lined with the "relationship of the university with business structures".

This block has been divided into three categories which reflect the main area of relationships development between the main shareholders. The corporate relations department is engaged in the following tasks within each of the areas:

B1. Maintaining relationships with existing partner companies: promoting the informational materials of the partner companies at the Internet webpage of the business school (including online resources); organizing educational and vocational guidance activities (workshops, seminars, training sessions, etc.) with the participation of managers and specialists from the companies; maintaining research and consulting projects carried out by the students on request of the companies within research practice or individual courses; organizing and holding the event "Day of the Partner Company" in the business school; inviting the partners to participate in the Diploma and Term Papers Defense Commissions.

B2. Promoting professional orientation and employment of students and graduates: coordinating trainings, production, research and pre-diploma practice of Bachelor and Master students; organizing student internships in companies outside the framework of the curriculum; promoting employment of the graduates; organizing and holding Career Days and Round Tables on employment and career building; organizing participation of the students in companies' tournaments of business cases; writing theses with the focus of essential problems of the companies. 
B3. Promoting the business school divisions in attracting organizations and external experts to the participation in educational, scientific and practical activities: organizing guest lectures of the managers and specialists from companies and coordinating training courses implemented by the representatives of companies; inviting representatives of the companies in the whole faculty and all-university scientific and practical activities; organizing volunteer activities of the students.

The research made by Mariusz Jas, Tomasz Jurczyk, Tomasz Kamiński, Maciej Kozakiewicz, Michał Sędkowski, Michał Tomczyk, and Piotr Wiąckiewicz (2013) confirms that such a form of cooperation can build motivation for self-improvement among the students as well as support the networking between the main shareholders. The students of business schools which use such form of cooperation can contact with potential employers and start their career before the graduation. It has also an impact on the psychological conditions of the students. They are more convinced about their employment opportunity after graduating from the school.

As a result of the research, the authors suggest a matrix of interaction between universities and partner companies comprising tangible/intangible resources and tangible/intangible effects with the appropriate areas of interaction and the characteristics of their impact and effectiveness for companies.

First, we consider the notions of "resources" and "effects", as well as the factors that determine their tangible and intangible nature. The resources can include all kinds of the additional costs of the partner company, related to the partnership. Tangible (material) costs are additional financial incentives of the partner company's employees (master classes and presentations by representatives of the company, organizing and conducting tours for students at the site of the company), preparation of souvenirs and product samples for distributing among participants in the frame of joint activities, preparation of promotional and informational materials for placing on the high school's site. All these costs are accompanied by corresponding time expenses. In addition to material costs, the partnership may require intangible (non-material) costs such as the time (for example: supervising interns and student projects (in this case supervision can often relate to direct work duties of employees of the company); participation in joint professional orientation and public relations events organized and conducted by the high school; participation in scientific, practical and graduation events held by the high school).

In turn, cost savings first of all refer to the material (economic) effects for the partner company: promotion of the employer company's brand; search and selection of candidates for the intern vacancies; marketing research and the purchase of analytical reports; the implementation of certain operational tasks, plans and projects.

Intangible effects may include: increasing brand awareness of the employer and the formation of interest of students and graduates towards its career suggestions; formation of favorable attitude of students, graduates and their closest associates to the company as an employer and its business as a whole; expanding the network of business contacts through participation in activities, covering companies from various sectors and industries, as well as student startups (Table 1). 
Table 1. A matrix of interaction between universities and partner companies: "tangible/intangible resources" and "tangible/intangible effects" (source: created by authors)

\begin{tabular}{|c|c|c|c|}
\hline \multirow{2}{*}{\multicolumn{2}{|c|}{$\begin{array}{c}\text { RESOURCES/ } \\
\text { EFFECTS } \\
\text { tangible }\end{array}$}} & \multicolumn{2}{|c|}{ Effects (outcomes) } \\
\hline & & intangible & \\
\hline \multirow[t]{2}{*}{$\begin{array}{l}\text { Resources } \\
\text { (inputs) }\end{array}$} & $\begin{array}{l}\text { tangible } \\
\text { (direct, } \\
\text { material) }\end{array}$ & $\begin{array}{l}\text { - placing informational materials } \\
\text { of partner companies at the site } \\
\text { of the high school (including on- } \\
\text { line resources); } \\
\text { - organizing student internships } \\
\text { in companies outside the frame- } \\
\text { work of the curriculum; } \\
\text { - promoting employment of the } \\
\text { graduates. }\end{array}$ & $\begin{array}{l}\text { - placing informational materials } \\
\text { of partner companies at the site of } \\
\text { the high school (including online } \\
\text { resources). }\end{array}$ \\
\hline & $\begin{array}{l}\text { intangible } \\
\text { (indirect, } \\
\text { non-material) }\end{array}$ & $\begin{array}{l}\text { - maintaining research and con- } \\
\text { sulting projects carried out by } \\
\text { the students in the interests and } \\
\text { on request of the companies } \\
\text { within research practice or in- } \\
\text { dividual courses; } \\
\text { - organizing and holding Career } \\
\text { Days on employment and career } \\
\text { building; } \\
\text { - organizing volunteer activities } \\
\text { of the students; } \\
\text { - coordinating training, produc- } \\
\text { tion, research and pre-diploma } \\
\text { practice of Bachelor and Master } \\
\text { students; } \\
\text { - organizing participation of the } \\
\text { students in companies' tourna- } \\
\text { ments of business cases; } \\
\text { - - inviting the partners to par- } \\
\text { ticipate in the commissions for } \\
\text { defense of diploma works. and } \\
\text { term papers. }\end{array}$ & $\begin{array}{l}\text { - organizing educational and voca- } \\
\text { tional guidance activities (work- } \\
\text { shops, seminars, training sessions, } \\
\text { etc.) with participation of manag- } \\
\text { ers and specialists from the com- } \\
\text { panies; } \\
\text { - organizing and holding Round } \\
\text { Tables on employment and career } \\
\text { development; } \\
\text { - organizing guest lectures of the } \\
\text { managers and specialists from } \\
\text { companies and coordinating train- } \\
\text { ing courses implemented by the } \\
\text { representatives of companies; } \\
\text { - organizing participation of the stu- } \\
\text { dents in companies' tournaments of } \\
\text { business cases; } \\
\text { - inviting representatives of the } \\
\text { companies in the whole faculty } \\
\text { and all-university scientific and } \\
\text { practical activities. }\end{array}$ \\
\hline
\end{tabular}

It is worth noting that the same area of cooperation (reference to the text in italics in Table 1) can bring both an economic and communication effects to the partner company of the university. For example, placing informational materials of partner companies at the site of the high school (including online resources) serves for the objectives of cost savings on brand promotion of the employer, the objectives of increasing brand awareness of the employer and the formation of interest of students and graduates towards its career suggestions. Organizing participation of the students in companies' tournaments of business cases will serve as for the objectives of cost savings on the search and selection of candidates for the intern vacancies, market research and the purchase of analytical reports, and for the objectives of creating favorable attitude of students, graduates and their closest associates to the company as an employer and its business as a whole. 
In this model, the activities corresponding to the left lower quadrant are the most interesting. They do not require a lot of time and financial costs from the potential and actual partners or, in general, do not even require additional costs for the implementation. However, they can lead to significant tangible financial and communication effects for the companies. These activities based on the events are not only low-cost but also build networking and uphold existing relationships. The positive correlation between events and relationship building is known and used by companies. There is no reason why universities would not practice the same approach in their programs.

The final stage of the research was a survey among employers, the companies collaborating with MSU Business School in the spring of 2016. The survey was conducted using questionnaires, offered to the representatives of partner companies to fill in during the Round Table devoted to the issues of employment and organized by the Business School. During the survey the authors identified the most attractive Business School's activities for the partner companies (Table 2).

Table 2. The most attractive business school's activities for the partner companies (source: created by authors)

\begin{tabular}{|c|l|}
\hline \multirow{2}{*}{$\begin{array}{c}\text { For quality } \\
\text { recruitment }\end{array}$} & Participation in Career Days and Round Tables on employment. \\
\cline { 2 - 3 } & $\begin{array}{l}\text { Interaction with the Career Center of the business school (informational, } \\
\text { recruitment, etc.). }\end{array}$ \\
\cline { 2 - 3 } $\begin{array}{c}\text { For promotion } \\
\text { of the employer's } \\
\text { brand }\end{array}$ & Business cases competitions. \\
\cline { 2 - 2 } & $\begin{array}{l}\text { Guest lectures, master-classes from top-managers. } \\
\text { at the Open Days. }\end{array}$ \\
\cline { 2 - 3 } & Invitation to the events outside the university (at the company's site). \\
\hline
\end{tabular}

Activities related to the quality recruitment bring more "tangible" results for the partner company, in turn, activities related to the promotion of the employer brand brings more "intangible" results. In this case, both the first and the second directions are tactically important for the development of the partners and therefore motivate them to cooperate with the university and business school. At the same time, these activities increase the students' motivation to study and improve their overall satisfaction with the education received. Such mutual benefits are inscribing into the "win-win outcomes" in the game theory and is perceived as the fundamental in the process of building successful relationship and partnership (Spangler, 2013).

\section{Conclusions}

A major factor that reduces the quality of study at the universities is omni-directional students' objectives, expecting immediate success just after the graduation, mostly unrelated to qualifications and knowledge. As a result, the motivation of students to study is decreasing, affecting negatively the performance of the lecturers. The findings suggest the need to improve vocational guidance system through systematic interaction between schools and 
universities. The business schools have all the necessary resources (lecturers, educational materials, etc.) to promote the entrepreneurial thinking and attractive image of entrepreneurship among students. While the companies will have the opportunity to select the most motivated students, the business school will contribute to the development of both entrepreneurship and entrepreneurial spirit. In consequence, the students will learn more effectively to become entrepreneurs, contributing to the country's economic development.

The authors have proposed activities for the business schools that do not require significant financial or time costs from the partner companies, as they fit into the framework of ongoing activities. These activities will contribute to the improvement of the quality of vocational guidance and motivation of the students and the quality of graduates. In turn, these conditions will increase the loyalty of the partner organizations, both domestic and foreign ones, and motivate them to further cooperation, including the use of digital technologies.

\section{References}

Ackerman, R., \& Schibrowsky, J. (2007). A business marketing strategy applied to student retention: a higher education initiative. Journal of College Student Retention: Research, Theory \& Practice, 9(3), 307-336. https://doi.org/10.2190/CS.9.3.d

Al-Alak, B. A. M. (2006). The impact of marketing actions on relationship quality in the higher education sector in Jordan. Journal of Marketing for Higher Education, 16(2), 1-23. https://doi.org/10.1300/J050v16n02_01

Barlow, R. G. (2000). Frequency marketing - what's next? Direct Marketing, 69(9), 2-23.

Bennett, R. (2006). Predicting the lifetime durations of donors to charities. Journal of Nonprofit \& Public Sector Marketing, 15(1-2), 45-67. https://doi.org/10.1300/J054v15n01_03

Berry, L. L. (2002). Relationship marketing of services perspectives from 1983 and 2000. Journal of Relantionship Marketing, 1(1), 59-77. https://doi.org/10.1300/J366v01n01_05

Białoń, L. (2015). Creating marketing strategies for higher education institutions. Marketing of Scientific and Research Organizations, 18(4), 129-146.

Binsardi, A., \& Ekwulugo, F. (2003). International marketing of British education: research on the students' perception and the UK market penetration. Marketing Intelligence \& Planning, 21(5), 318-327. https://doi.org/10.1108/02634500310490265

Bowden, J., \& Wood, L. (2011). Sex doesn't matter: the role of gender in the formation of studentuniversity relationships. Journal of Marketing for Higher Education, 21(2), 133-156. https://doi.org/10.1080/08841241.2011.623731

Carvalho, S. W., \& Oliveira Mota, de M. (2010). The role of trust in creating value and student loyalty in relational exchanges between higher education institutions and their students. Journal of Marketing for Higher Education, 20(1), 145-165. https://doi.org/10.1080/08841241003788201

Constantin, C. (2011). The need of relationship marketing in higher education. Bulletin of the Transilvania University of Braşov, 4(53), 19-26.

DeShields, Jr. O. W., Kara, A., \& Kaynak, E. (2005). Determinants of business student satisfaction and retention in higher education: applying Herzberg's two-factor theory. International Journal of Educational Management, 19(2), 128-139. https://doi.org/10.1108/09513540510582426

Domański, T. (2014). Marketing of higher education: future challenges. Management and Business Administration. Central Europe, 22(4-127), 118-132.

Drapińska, A. (2016). A concept of student relationship management in higher education. Marketing of Scientific and Research Organizations, 227(6), 35-49. https://doi.org/10.5604/05096669.1076706 
Fontaine, M. (2014). Student Relationship Management (SRM) in higher education: addressing the expectations of an ever evolving demographic and its impact on retention. Journal of Education and Human Development, 3(2), 105-119.

Gattermann Perin, M., Sampaio, C. H., Simões, C., \& Pólvora de Pólvora, R. (2012). Modeling antecedents of student loyalty in higher education. Journal of Marketing for Higher Education, 22(1), 101-116. https://doi.org/10.1080/08841241.2012.705797

Grönroos, Ch. (1989). Defining marketing: a market-oriented approach. European Journal of Marketing, 23(1), 52-60. https://doi.org/10.1108/EUM0000000000541

Guolla, M. (1999). Assessing the teaching quality to student satisfaction relationship: applied customer satisfaction research in the classroom. Journal of Marketing Theory and Practice, 7(3), 87-97. https://doi.org/10.1080/10696679.1999.11501843

Helgesen, Ø. (2008). Marketing for higher education: a relationship marketing approach. Journal of Marketing for Higher Education, 18(1), 50-78. https://doi.org/10.1080/08841240802100188

Jas, M., Jurczyk, T., Kamiński, T., Kozakiewicz, M., Sędkowski, M., Tomczyk, M., \& Wiąckiewicz, P. (2013). Connection - innowacyjny model współpracy uczelni z biznesem: Podręcznik wdrażania. Retrieved from https://www.academia.edu/7153191/Connection_-_innowacyjny_model_współpracy_ uczelni_z_biznesem._Podręcznik_wdrażania

Jurkowitsch, S., Vignali, C., \& Kaufmann, H.-R. (2006). A student satisfaction model for austrian higher education providers considering aspects of marketing communications. Innovative Marketing, 2(3), $9-23$.

Letcher, D. W., \& Neves, J. S. (2010). Determinants of undergraduate business student satisfaction. Research in Higher Education Journal. Retrieved from https://pdfs.semanticscholar.org/8 722/15a270f8b802c9ac79abee5ae61d221573df.pdf?_ga=2.159627133.1319863547.1557070264199233841.1528889777

Litten, L. H. (1980). Marketing higher education: benefits and risks for the american academic system. The Journal of Higher Education, 51(1), 40-59. https://doi.org/10.2307/1981124

Lynn, M. (2011). Segmenting and targeting your market: strategies and limitations. Retrieved from https://scholarship.sha.cornell.edu/cgi/viewcontent.cgi? article=1238\&context=articles

McAlexander, J. H., Koenig, H. F., \& Schouten, J. W. (2006). Building relationships of brand community in higher education: a strategic framework for university advancement. International Journal of Educational Advancement, 6(2), 107-118. https://doi.org/10.1057/palgrave.ijea.2150015

Moore, D., \& Lay-Hwa. Bowden-Everson, J. (2012). An appealing connection - the role of relationship marketing in the attraction and retention of students in an Australian tertiary context. Asian Social Science, 8(14), 65-80. https://doi.org/10.5539/ass.v8n14p65

Negricea, C. I., Avram, E. M., \& Eftimie, R. C. (2011). Development and implementations of relationship marketing principles in Romanian higher education environment. Romanian Economic and Business Review, 6(2), 44-51.

Nicholls, J., Harris, J., Morgan, E., Clarke, K., \& Sims, D. (1995). Marketing higher education: the MBA experience. International Journal of Educational Management, 9(2), 31-38. https://doi.org/10.1108/09513549510082369

Nicolescu, L. (2009). Applying marketing to higher education: scope and limits. Management \& Marketing, 4(2), 35-44.

Oluseye, O. O., Tairat, B. T., \& Emmanuel, J. O. (2014). Customer relationship management approach and student satisfaction in higher education marketing. Journal of Competitiveness, 6(3), 49-62. https://doi.org/10.7441/joc.2014.03.04

Powell, K. K., \& Powell Rey, M. (2015). Do they really know their customers? Exploring relationship marketing from the student stakeholder perspective. Journal of Management and Marketing Research, 19, 1-14. 
Rashid, T., \& Raj, R. (2006). Customer satisfaction: relationship marketing in higher education e-learning. Innovative Marketing, 2(3), 24-34.

Rouse, M., \& Aberle, L. (2019). Relationship marketing. Search customer experience. Retrieved from https://searchcustomerexperience.techtarget.com/definition/relationship-marketing

Saelee, R., Jhundrain, P., \& Muenthaisong, K. (2015). A conceptual framework of customer relationship management capability and marketing survival. Proceedings of the Academy of Marketing Studies, 20(2), 94-105.

Seliga, R., \& Chmielecki, M. (2012). International marketing in higher education - a comparison study between students' choices in Poland and the UK. Journal of Intercultural Management, 4(4), 94-101.

Spangler, B. (2013). Win-Win/Win-Lose/Lose-Lose situations. Beyond Intractability. Retrieved from https://www.beyondintractability.org/essay/win-lose

Tonks, D. G., \& Farr, M. (1995). Market segments for higher education: using geodemographics. Marketing Intelligence \& Planning, 13(4), 24-33. https://doi.org/10.1108/02634509510089008

Umbach, P. D., \& Porter, S. R. (2002). How do academic departments impact student satisfaction? Understanding the contextual effects of departments. Research in Higher Education, 43(2), 209-234. https://doi.org/10.1023/A:1014471708162

Zaksa, K. (2012). Higher education marketing abroad and in Latvia. Economics and Management, 17(4), 1507-1515. https://doi.org/10.5755/j01.em.17.4.3021

\title{
KŪRYBINIS AR ANALITINIS KARJEROS PLĖTROS KELIAS? SANTYKIŲ RINKODARA TARPTAUTINIO ŠVIETIMO VERSLO SRITYJE
}

\author{
Marina MARKOVA, Artur MODLIŃSKI, Luís MOREIRA PINTO
}

\begin{abstract}
Santrauka
Straipsnyje pristatomas partnerystès švietimo verslo srityje strateginis modelis, atsižvelgiant ị globalizacijos specifiškumą ir dabartines tendencijas darbo rinkose. Pagrindiniai tyrimo uždaviniai - apsvarstyti santykių rinkodaros teorinius pagrindus bei išnagrinèti svarbiausias tendencijas ir iššǔkius, kylančius Rusijos darbo rinkoje. Straipsnis apima tyrimo, skirto vidurinių mokyklų moksleivių gyvenimo tikslams ir motyvacijai, rezultatus, universitetų profesorių apklausą apie jų nuomonę, kodèl moksleiviai nusprendžia studijuoti, taip pat Europos ir Rusijos universitetų studentų tarptautinį tyrimą. Straipsnyje pristatoma ịvairi veikla, kurią verslo mokyklos gali pasitelkti siekdamos paskatinti pagrindinių akcininkų bendradarbiavimą. Autoriai siūlo universitetų ir bendrovių partnerių sąveikos matricą, kurią sudaro apčiuopiami / neapčiuopiami ištekliai ir apčiuopiamas / neapčiuopiamas poveikis bei jų ittakos charakteristikos ir veiksmingumas tiek bendrovèms, tiek universitetams.
\end{abstract}

Reikšminiai žodžiai: švietimas verslo srityje, sąveika, darbo rinka, santykių rinkodara. 